\title{
Volume Contents
}

VOLUME 38, NO. 1

Editorial: Mission Studies in Contact Zones $\quad 1-4$

Norbert Hintersteiner, Sara Fretheim, and Dorottya Nagy

Obituary for Edith Blumhofer (April 24, 1950-March 5, 2020) 5

Darrell Whiteman

Obituary for Franz Kangler CM (May 27, 1950-February 23, 2021) 6

Claudio Monge $O P$

\section{Articles}

The Missionary in the World: The Invention of the Soul of Saint Francis Xavier in an Anonymous Sermon: The East, Quito and Rome, 18th Century 7-30

Rafael Gaune and Maria Montt Strabucchi

Negotiating Norwegian Mission Education in Zululand and Natal during World War II $\quad 31-58$

Ellen Vea Rosnes

Secularizing Effects of Christian Mission: Fifty Years After Elmer Miller's “The Christian Missionary, Agent of Secularization” $\quad 59-76$ Maryse Kruithof

Turangawaewae as the Means of Moving from Migrant to Mission Worker: Identification Strategies in Embracing the Context and the People $\quad 77-97$ Mario Weyers

"Keep Your Mind in Hell and Despair Not": Dealing with the Wounds and Complicities of 2oth Century Orthodoxy in Estonia Through the Theology of St Sophrony (Sakharov) and Arvo Pärt 98-118 Irina Paert

Wounded Because of Religion: Identifying the Components of GenderSpecific Religious Persecution of Christians 119-141 Helene Fisher, Elizabeth Lane Miller and Christof Sauer Missional Christian Communities in Conditions of Marginality: On Finding a 'Missional Existence' in the Post-Christian West $\quad 142-160$ Stefan Paas 


\section{BOOK REVIEWS}

Mark W. Hamilton.Jesus, King of Strangers: What the Bible Really Says about Immigration 161-162

Afia Sun Kim

Gwyn McClelland. Dangerous Memory in Nagasaki: Prayers, Protests and Catholic Survivor Narratives $\quad$ 162-163

Sarah Bacaller

Luke Bretherton. Christ and the Common Life. Political Theology and the Case for Democracy 164-165

Pavol Bargár

Sabine Dedenbach-Salazar Sáenz. Translating Wor [l]ds: Christianity across Cultural Boundaries 165-166

Stephen Bevans, svD

Andrew Peh. Of Merchants and Missions. A Historical Study of the Impact of British Colonialism on American Methodism In Singapore from 1885

to $1910 \quad 166-168$

Tobias Brandner

Paul Gifford. The Plight of Western Religion: The Eclipse of the

Other-Worldly 168-169

Atola Longkumer

Sebastiano D'Ambra, PIME. Interreligious Dialogue: The Mission of Dialogue and Peace in the Light of the Beatitudes $\quad 169-170$

Abigael M. Maitim

Henning Wrogemann. Intercultural Hermeneutics: Intercultural

Theology 170-174

Michael Nausner

Antony Mecherry, S.J. Testing Ground for Jesuit Accommodation in Early Modern

India: Francisco Ros SJ in Malabar (16th-17th Centuries) $\quad$ 174-175

B.L. Nongbri

Anneth Munga. Wenzi wa wachungaji na kanisa 176

Mika Vähäkangas

List of Contributors $\quad 177-179$

IAMS Notice 181

Paul Kollman and Aron Engberg 
VOLUME 38, NO. 2

Editorial 183

Norbert Hintersteiner

Obituary for Fr Larry Nemer SVD (24 November 1932-9 June 2021) 184 Xiaoli Yang

Obituary for Carlos René Padilla (12 October 1932-27 April 2021) 185 Mariel Deluca Voth

Obituary for Andrew N. Porter (12 October 1945-4 March 2021) 186 Brian Stanley

Obituary for Robert J. Schreiter C.PP.S

(14 December 1947-1 June 2021) 187-188

Stephen Bevans, $s V D$

\section{ARTICLES}

Learning from "Fresh Expressions of Church" and the "Loving-First Cycle" through a Case Study from Cape Town 189-212

Benjamin Aldous and Michael Moynagh

Colonial Politics, Missionary Rivalry, and the Beginnings of Seventh-Day Adventist Mission in Northern Nigeria $\quad 213-235$

John Garah Nengel† and Chigemezi Nnadozie Wogu

The Persistence of Igbo Worldview in the Sabbath Church Healing Liturgy and Praxis 236-255

Ndidi Justice Gbule and Chigozie Samuel Nwaka

Identity and Nation-Building: Intercultural Reading of Isaiah 56-66

in the Ghanaian Context $\quad 256-277$

Nicoletta Gatti

Marginalization and Negotiation of Boundaries: The Case of the Armenian Church in Iran 278-296

Sara Afshari

\section{BOOK REVIEWS}

Frank J. Butler. Belonging: One Catholic's Journey $\quad$ 297-298 Fides del Castillo 
Ronnie P. Campbell and Christopher Gnanakan. Do Christians, Muslims, and Jews Worship the Same God? Four Views 298-299 Angel Santiago-Vendrell

Charles L. Cohen. The Abrahamic Religions: A Very Short

Introduction 300-301

John Mansford Prior

Majid Daneshgar. Studying the Qur'an in the Muslim Academy $\quad 301-302$ Charles M. Ramsey

Paul Gifford. The Plight of Western Religion: The Eclipse of the

Other-Worldly 302-303 Atola Longkumer

Daryl R. Ireland.John Song:Modern Chinese Christianity and the Making of a New Man 303-304 Rodney L. Petersen

Karen Lauterbach and Mika Vähäkangas, eds. Faith in African

Lived Christianity: Bridging Anthropological and Theological

Perspectives 305-306

Chammah J. Kaunda

Arthur Lin. The History of Christian Missions in Guangxi, China $\quad 306-307$ Jonathan A. Seitz

Antonia Pizzey. Receptive Ecumenism and the Renewal of the Ecumenical Movement: The Path of Ecclesial Conversion 307-309 Risto Jukko

Alberto Tiburcio. Muslim-Christian Polemics in Safavid Iran 309-310 Haila Manteghi

List of Contributors $\quad 311-312$

VOLUME 38, NO. 3

Special Issue: "Black/African Transatlantic Voices in Mission Studies"

Editorial $\quad 313-314$

Sara Fretheim

Guest Editorial $\quad 315-318$

Dwight A. Radcliff, Jr., Daniel Justice Eshun, and Damaris Parsitau

Obituary for Andrew Finlay Walls (21 April 1928-12 August 2021) 319-320

J. Kwabena Asamoah-Gyadu 
Obituary for Wilbert Ray Shenk (January 16, 1935-July 13, 2021) $\quad 321-322$ James R. Krabill

Obituary for Karel Adriaan Steenbrink (16 January 194222 August 2021) 323-324

Freek L. Bakker

\section{ARTiCLes}

Missions in Contested Places/Spaces: The SPG, Slavery, and Codrington

College, Barbados $\quad 325-349$

Janice McLean-Farrell and Michael Anderson Clarke

The Prophetic Lens: A Missiological Function of Film for Black Social

Movement from Martin Luther King, Jr. to the Camera Phone $\quad 35^{\circ}-371$ Phillip Allen

Speaking for Ourselves: The Ghanaian Encounter with European

Missionaries - Sixteenth-Twenty-first Centuries $\quad 372-397$

Daniel Justice Eshun

Racism and Religious Intolerance: A Critical Analysis of the Coloniality

of Brazilian Christianity $\quad 398-423$

Raimundo C. Barreto

Nigerian Pentecostal Diasporic Missions and Intergenerational Conflicts:

Case Studies from Amsterdam and London $\quad 424-447$

Bisi Adenekan-Koevoets

'Mama I Can't Breathe!': Black/African Women of Faith Groaning for Social Justice and Gender Equality $\quad 448-469$

Damaris Parsitau, Esther Mombo, Ini Dorcas Dah

and Tatiana Wairimu Gitonga

\section{BOOK REVIEWS}

Yolanda N. Pierce. In My Grandmother's House: Black Women, Faith, and the

Stories We Inherit $\quad 471-472$

Irene Amon

Israel Oluwole Olofinjana, ed. World Christianity in Western Europe:

Diasporic Identity, Narratives and Missiology $\quad 473-474$

Babatunde Adedibu 
Nimi Wariboko and Adeshina Afolayan, eds. African Pentecostalism and World Christianity: Essays in Honor of J. Kwabena Asamoah-Gyadu 474-475 Kyama M. Mugambi

Idara Otu. Communion Ecclesiology and Social Transformation in African Catholicism: Between Vatican II and African Synod II 476-477 George Ossom-Batsa

Brenda Salter McNeil. Roadmap to Reconciliation 2.0: Moving Communities Into Unity, Wholeness and Justice $\quad 477-478$ Patrick Wallace

Afe Adogame, Raimundo C. Barreto and Wanderley Pereira da Rosa, eds. Migration and Public Discourse in World Christianity 479-480 Jessie Fubara-Manuel

James Henry Harris. Black Suffering: Silent Pain, Hidden Hope $\quad 480-481$ Dwight A. Radcliff, Jr.

Chammah J. Kaunda and Julius Gathogo, eds. African Theology, Philosophy, and Religions: Celebrating John Samuel Mbiti's Contribution $\quad 481-483$ Laurenti Magesa

List of Contributors $\quad 485^{-486}$

IAMS Notice 487

Paul Kollman 